凍結・解凍効果を利用した食品廃棄物の脱水処理

\author{
四宮陽子 ${ }^{1 \dagger}$, 宮脇長人 ${ }^{2}$ \\ ${ }^{1}$ 実践女子大学生活科学部食生活科学科 \\ 2 東京大学大学院農学生命科学研究科応用生命化学専攻
}

\title{
Freezing-thawing Pretreatment for Dehydration of Food Waste
}

\author{
Yoko SHIMIYA $^{1 \dagger}$ and Osato MIYAWAKI ${ }^{2}$ \\ ${ }^{1}$ Department of Food and Health Sciences, Jissen Women's University, \\ Osakaue 4-1-1, Hino-shi, Tokyo, 191-8510 \\ ${ }^{2}$ Department of Applied Biological Chemistry, The University of Tokyo, \\ Yayoi 1-1-1, Bunkyou-ku, Tokyo, 113-8657
}

\begin{abstract}
Freezing-thawing dehydration, as a method with the less energy consumption for the reduction of food waste, was applied to about forty food-related samples chosen from vegetables and fruits, their waste, meat and fish, gel materials, and cooked food. Samples were frozen, thawed, and dehydrated either by centrifugation or compression. Freezing-thawing-dehydration treatment was very effective for vegetables and fruits, their waste, and gel materials to reduce their weight by 40 to $60 \%$ although it was not so effective for meat and fish. The average water content of samples decreased from $86.0 \%$ to $76.9 \%$ after the treatment. From these results and statistical data, 37\% reduction in weight was expected for the total kitchen refuse. Freezing-thawing-dehydration is expected to be effective for transportation, incineration, and composting of food waste.

Key words: freezing-thawing-dehydration, food waste reduction, centrifuge dehydration, compression dehydration, composting of food waste
\end{abstract}

\section{1. 緒言}

廃车物問題は，その処理に伴う環境負荷の発生，最 終処分場の逼迫，また，資源の有効利用の観点から，早 急に解決が求められる課題である。我が国の一般廃棄物 排出量は，年間約 5,000 万トン，1 1 人 1 日当たりでは約 $1,100 \mathrm{~g}$ になるが, この 1 人 1 日当たりのごみ量は世界 一多い[i]。年の内食品廃棄物は 1,600 万トン /年を占 め, 内訳は事業系 600 万トン /年, 家庭系 1,000 万卜 ン/年になる。その他に産業廃萧物として 340 万トン／ 年が排出されている，産業廃棄物の約半分は肥料化，飼 料化，その他の再生利用を行っているが，一般廃棄物 1,600（万トン／年）の約 99\% は焼却埋め立てされている のが現状である[1]．2001年 5 月に施行された「食品リ サイクル法」(食品循環資源の再生利用等の促進に関する 法律）[ii-iii]では，年間 100 トン以上の食品廃棄物を排

\footnotetext{
(受付 2004 年 3 月 8 H，受理 2004 年. 6 月 30 日)

1 ₹ 191-8510 東京都日野市大坂上 4-1-1

2 个113-8657 東京都文京区弥生 1-1-1

† Tel: 042-585-8891, Fax: 042-585-8818, E-mail: yshimiya@univ.jissen.ac.jp
}

出する事業者に対して 5 年間で $20 \%$ の排出減を義務づけ たが，もっとも多く排出している家庭系は対象外である. 食品廃棄物の特徵は，水分が多いこと，加工・調理 の過程で塩分や油が多くなることなどであるが, 乾燥か ら焼却までのエネルギーや焼却の過程で発生するダイオ キシン等を考慮すると，食品廃棄物は焼却には向かな い。さらに，食品廃棄物の多量の水分は腐敗やに打いの 原因にもなり, 肥料や飼料への変換においても前処理と して脱水が必要である，加熱による水分蒸発には多くの エネルギーが必要なので，それ以外の省エネルギー的で 家庭など小規模でも使用可能で安全な脱水方法の開発 が望まれている。

食品中の水分は細胞や組織内に保たれているので, 効 率よく脱水するためには前処理としてそれらを破壊する ことが望ましい，加熱によっても細胞構造は破壊される が, でんぷん糊化, タンパク質変性, 種々の相互反応等 が起こると, 逆に保水性が高まることや, 諸反応による ガスの発生なども考慮する必要が出てくる，粉砕による 物理的破壊もあるが，微細な粉砕物と水分との分離は困 難な操作になる可能性がある。一方凍結は，凍結時に形 
成される氷結晶が細胞構造を破壊するのみならず，凍結 変性, 凍結濃縮, 水和状態の変化等により, 解凍後は 水分を分離しやすくなる。食品廃棄物，とくに家庭系食 品廃棄物の $40 \sim 60 \%$ は野菜や果物の調理くずや食べ残 しであるが[2]，一般に植物細胞は動物細胞に比較して， 凍結耐性が低く[3-4], 凍結・解凍操作により細胞膜構 造が破壊され物性が大きく変化し[5-6]，脱水しやすく なる[7]ことが報告されている。また，凍結・解凍操作に 要するエネルギーは乾燥の約 $1 / 7$ であり, 省エネルギー 的である. 凍結・解凍操作による脱水効果への影響に関 しては，食品以外では上水抢よび下水污泥の脱水に関し て古くから研究されている[8-9]。 また，アンデス地方 (ペルー) のチューニョや北海道のしばれ芋は，凍結・ 解凍を利用して脱水した加工品と考えられるが, 食品に 関しては著者らの予備的報告[7]を除いて，これまでに ほとんど報告例がない，そこで，本論文では約 40 種類 の食品打よび調理くずに対して凍結 - 解凍処理と脱水操 作を組み合わせて行い，凍結・解凍処理の脱水効果につ いて検討した。

\section{2. 実験}

\section{1 試料}

試料は市販品を用い，野菜・果物は一般的な調理に 用いるように皮や芯などの調理くずを可食部と分離した. 肉や魚は可食部を購入した。加工品は一定のメ一カーの ものを使用した。これらの食品は部位差をなくすために $7 \sim 8 \mathrm{~mm}$ 角に切断して均一に混ぜて測定した。調理 食品は切断した後に食品によって 8 〜 20 分ゆでた。飯 は炊飯ジャーで炊いた。測定した食品試料は, 野菜・果 物の調理くず（皮，芯，種など） 11 種類，水分含量 $90 \%$ 以上の野菜・果物 11 種類，水分含量 $90 \%$ 以下の野菜· 果物 4 種類, 肉. 魚 2 種類, ゲル状食品 4 種類, 調理 食品 5 種類である。

\section{2 凍結・解凍方法}

重量を測定した 50 〜 $60 \mathrm{~g}$ の試料を、ビニル袋（ポ リエチレン製，（株）紙叶）の中にメッシュ袋（高密度 ポリエチレン製，ニッコー（株）を入れて作製した凍結 用袋に入れて密閉し，家庭用冷凍冷蔵庫（東芝 SF GR-437SIB，東芝）に入れ $-18{ }^{\circ} \mathrm{C} て ゙ 24$ 時間以上かけて完 全に凍結させた。解凍は条件を調べるために, 凍結用袋 に入れたまま $5{ }^{\circ} \mathrm{C}$ 冷蔵庫内と $37{ }^{\circ} \mathrm{C}$ 湯㳂で解凍したが, 解凍温度は脱水後の残さ重量にあまり影響しないことが 判明したので，最終的には室温で解凍することとした。

\section{3 脱水方法}

凍結・解凍した試料は，凍結用袋のメッシュ袋のみ 10 秒間持ち上げて残さとドリップに分離し，重量を測
Double centrifugal tube

Compressor

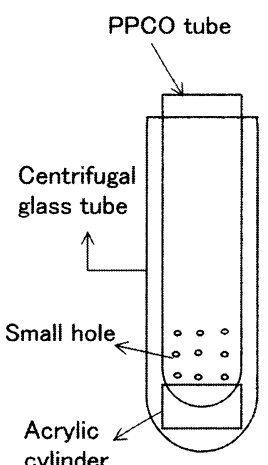

$10 \mathrm{Kg}$

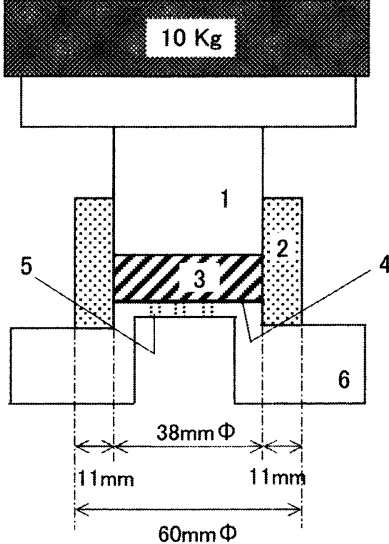

Fig. 1 Apparatus for dehydration.

1. Inner cylinder, 2. Outer cylinder, 3. Sample, 4. Paper filter,

5. Orifice, 6.Aluminium plate

定してから残さを脱水した。遠心分離による脱水では， Fig. 1 に示すようにガラス遠沈管 $(50 \mathrm{ml}$, KUBOTA) 内 部に通水孔をあけたPPCO 管 (50 ml, NALGENE) とアクリル円筒（外径 $25 \mathrm{~mm}$ 高さ $15 \mathrm{~mm}$ ）を入れて, ドリップを分離できるようにした二重遠沈管を用いた。 脱水効果の測定では遠沈管に約 $5 \mathrm{~g}$ の試料を入れ，遠心 機（ユニバーサル冷却遠心機 5700 ，久保田商事（株） で 2328 xg (3500 rpm)，30 分間遠心分離した。

荷重压搾では，Fig. 1 に示すようにアルミニウム底板 部に通水孔を開けたピストン状の荷重圧搾器を作製した。 底板部の上にろ紙を敷き，精科した試料約 $20 \mathrm{~g}$ を外筒部 に入れ，0.0865 MPa（10 kg）で 30 分間圧搾した。た だし，解凍条件を調べる実験では，2 枚のプレートには さんで荷重を $0.01 〜 0.04 \mathrm{MPa}$ と変化させて圧搾した。

\section{4 凍結・解凍操作の脱水効果の評価}

凍結・解凍操作の評価は, 凍結・解凍しないで脱水し た試料を詨照として比較した。脱水効果は水分含量と残 さ重量比で評価した，水分含量は $105{ }^{\circ} \mathrm{C}$ 常圧乾燥法で測 定したが，果物は糖が多量に存在するので $135{ }^{\circ} \mathrm{C}$ 常圧乾 燥法で 2 時間乾燥した。脱水後の残さ重量比は, 試料量 が少なく重量測定では採取時のロスなどによる誤差が大 きくなったため，下のように水分含量から換算して求めた。

$$
\mathrm{Y}=(1-\mathrm{A}) /(1-\mathrm{B})
$$

ただし，100Y：脱水前と比較した脱水後の残さ重量比 $(w t \%), 100 \mathrm{~A}$ : 脱水前の水分含量 $(w t \%), 100 \mathrm{~B}$ : 脱 水後の水分含量（wt\%）である.

\section{3. 結果}

\section{1 凍結・解凍条件の影響}

一般に，食品の凍結過程においては，最大水結晶生成 
Table 1 Samples to test the effect of thawing temperature.

\begin{tabular}{ll}
\hline $\begin{array}{l}\text { Waste } \\
\text { (Vegetables \& fruits) }\end{array}$ & $\begin{array}{l}\text { Sapanese radish (skin), Potato (skin), Apple } \\
\text { (skin), Cabbage (core) }\end{array}$ \\
$\begin{array}{l}\text { Vegetables \& fruits } \\
\text { (water content }>90 \%)\end{array}$ & $\begin{array}{l}\text { Eggplant, Sweet pepper, Japanese radish, } \\
\text { Cucumber, Chinese cabbage }\end{array}$ \\
$\begin{array}{l}\text { Vegetables \& fruits } \\
\text { (water content }<90 \%)\end{array}$ & Apple, Carrot, Broccoli \\
Meat \& fish & Chicken leg, Chicken meat, Tuna \\
Gel materials & Soybean curd, Konjak gel, Boiled egg white \\
\hline
\end{tabular}

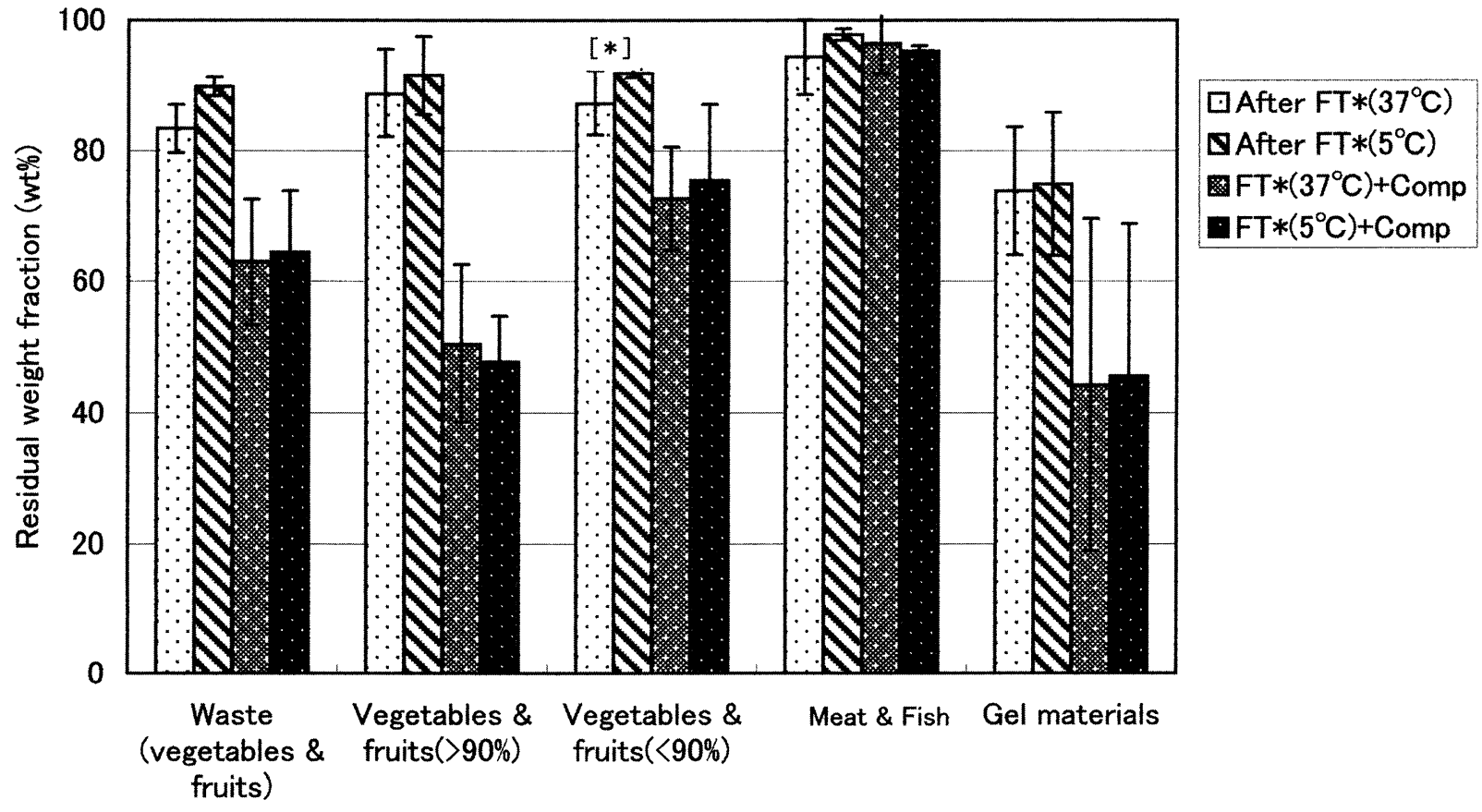

Fig. 2 Effect of thawing temperature on the residual weight fraction of food samples after freezing - thawing and compression.

$\mathrm{FT}^{\star}$; freezing-thawing, Comp; compression with 0.01-0.04 MPa.

*) significance level ( $a=5 \%)$

帯通過時間の長い緩慢凍結においては食品品質に対する 損失がより大きくなることが知られている[10].このこ とと，家庭等でも容易に操作可能であることとを考慮し て, 家庭用冷凍冷蔵庫 $\left(-18{ }^{\circ} \mathrm{C}\right)$ で緩慢凍結を行った。 さらに, 冷凍食品の解凍に打いては, 解凍終温度は食品 品質に影響するため[11]，解凍温度は脱水率にも影響す る可能性があると考えられたので, 食品の各グループか ら 3 〜 種を選んで (Table 1)，解凍温度を $37^{\circ} \mathrm{C}$ と $5{ }^{\circ} \mathrm{C}$ に変えて荷重圧搾（0.01 0.04 MPa, 30 min）に
よる脱水への影響を調べた。 Fig. 2 は $37{ }^{\circ} \mathrm{C} と 5{ }^{\circ} \mathrm{C}$ 解凍 の解凍直後の処理前と比較した残さ重量比（wt％) と脱 水操作後の残さ重量比（wt％）を示す。野菜・果物は調 理くずも含めて解凍後の残さ重量比は $90 \%$ 程度であっ たが, 荷重圧搾によりさらに $20 \sim 40 \%$ の減量効果が見 られた。ゲル状食品は解凍後の残さ重量比が約 $75 \%$ と かなり減少したが, 荷重圧搾によりさらに $40 \%$ 台にま で減量した。一方, 肉や魚は解凍抢よび荷重圧搾後の重 量変化は少なかった. 以上の結果の解凍温度 $37{ }^{\circ} \mathrm{C}$ と 
$5{ }^{\circ} \mathrm{C}$ による差を見ると, 解凍直後には $37{ }^{\circ} \mathrm{C}$ 解凍の方が 残さ重量が少ない傾向があったが， $\mathrm{t}$ 検定の結果有意差 が見られたのは水分 $90 \%$ 以下の野菜・果物の解凍後の みであり, 脱水後には各食品グループで一定の傾向は見 られなかった，冷凍魚の解凍においては，ドリップ量は 解凍終温度に影響され，解凍終温度が高い方がドリップ 量が多いとされている[11]. 今回の測定でも肉や魚以外 の食品にもその傾向は若干見られたが, 脱水操作後の脱 水率には解凍温度はあまり影響しないと考えられた。し たがって，以下の解凍操作は室温で行った。

\section{2 脱水条件の影響}

遠心分離と荷重圧搾における操作条件の影響を調べる ために, 凍結・解凍したダイコンとトウフを試料として 各操作条件による処理前と比較した脱水後の残さ重量比 （wt％）を調べた. Fig. 3A は遠心時間一定（30 分）で遠 心力を変化させた場合を示すが, 遠心時間が 30 分の場合

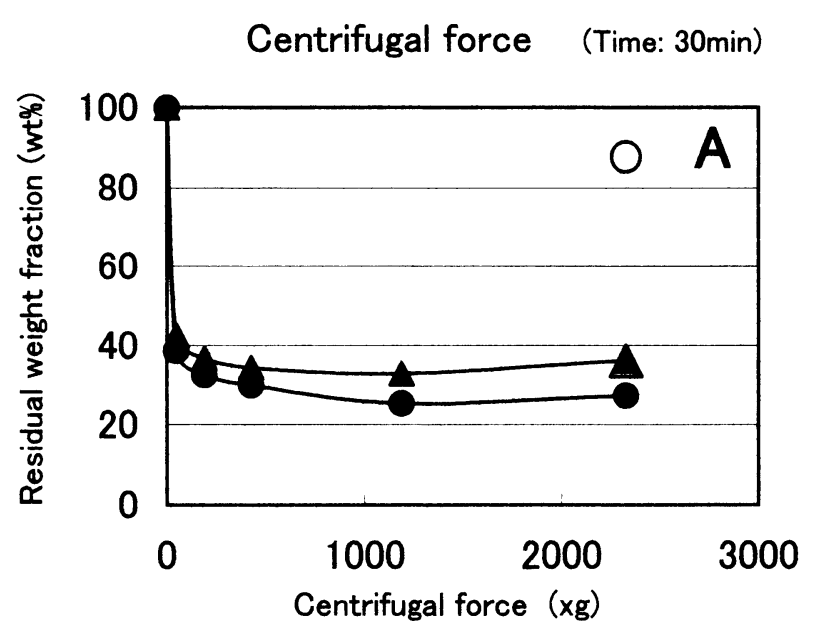

Centrifugal time (Force: 2328xg)

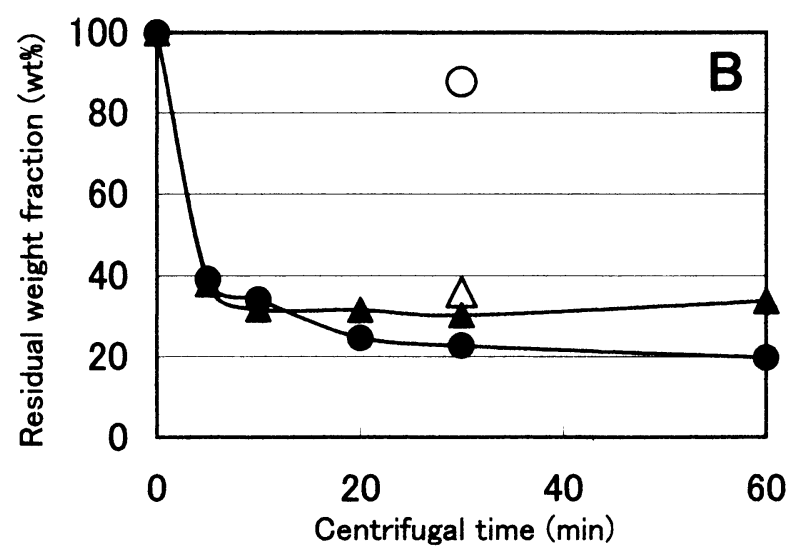

Fig. 3 Effect of centrifugal force (A) and time (B) on the residual weight fraction of food samples with or without freezingthawing.

; with $\mathrm{FT}^{\star}$ Japanese radish, $\boldsymbol{\Delta}$; with $\mathrm{FT}^{\star}$ Soybean curd, $\bigcirc$; without $\mathrm{FT}^{\star}$ Japanese radish, $\triangle$; without FT* Soybean curd.

*) freezing-thawing
Load (Loading time: $30 \mathrm{~min}$ )

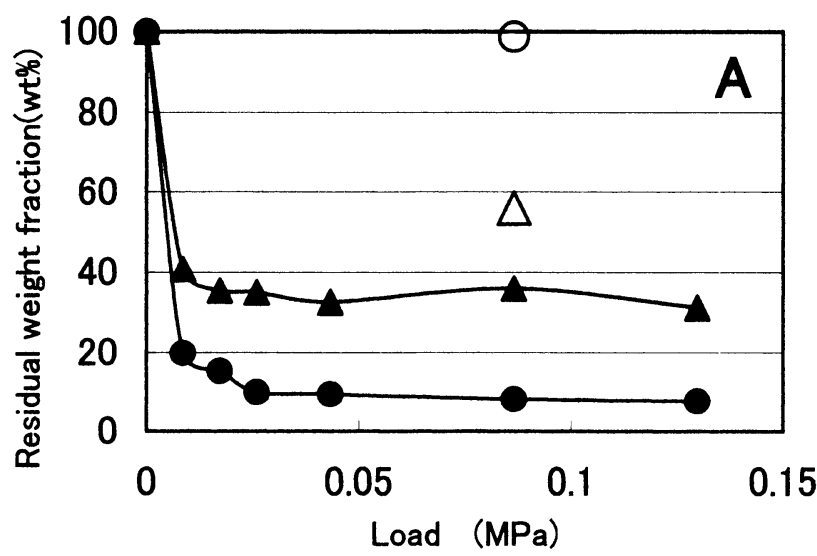

Loading time (Load: $0.0865 \mathrm{MPa}$ )

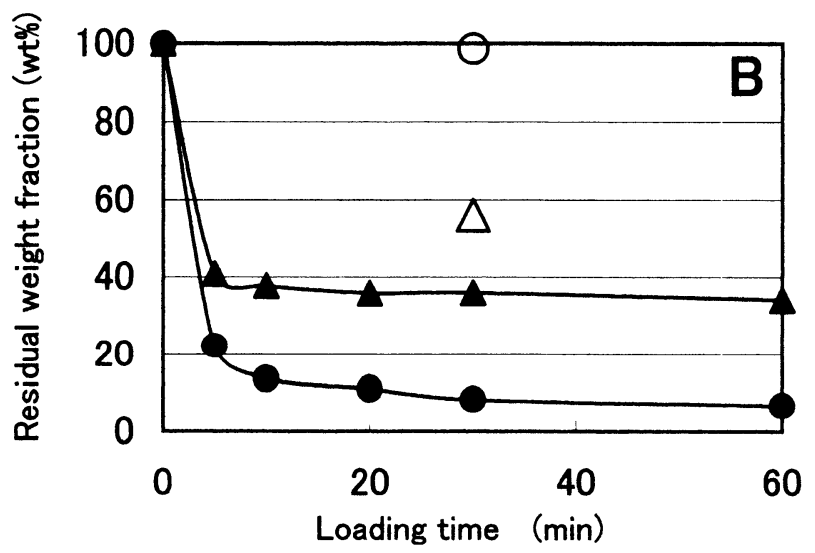

Fig. 4 Effect of the load (A) and loading time (B) on the residual weight fraction of food samples with or without freezing thawing.

- ;ith $\mathrm{FT}^{\star}$ Japanese radish, $\mathbf{\Delta}$; with $\mathrm{FT}^{\star}$ Soybean curd, $\mathrm{O}$; without $\mathrm{FT}^{*}$ Japanese radish, $\triangle$; without $\mathrm{FT}^{\star}$ Soybean curd. *) freezing-thawing

は遠心力が弱くても試料の残さ重量比は $40 \%$ 以下にな り，1188 x $g$ でほぼ一定になった。また，凍結・解凍 処理しないトウフは，した場合とほぼ同様に脱水してい たが、ダイコンは，凍結・解凍処理なしの場合，残さ重 量は $10 \%$ 程度しか減少しなかった。Fig. 3B は遠心力 一定 $(2328 \mathrm{xg})$ で時間を变化させた結果を示す。トウ フは 20 分程度で安定したが，ダイコンの残さ重量比は その後もわずかに減少し続けた．Fig. 4 は荷重圧搾の 結果で，同図 A は圧搾時間一定（30 分）で荷重を变化 させた場合である。トゥフの脱水は遠心分離と同程度で あったが，ダイコンは残さ重量比 $10 \%$ 程度にまで減少 し，いずれも $0.05 \mathrm{MPa}$ でほぼ一定となった。また，凍 結・解凍処理しないダイコンの残さ重量比はほとんど減少 せず，トウフは残さ重量比約 56\%であった。Fig. 4B は荷 重一定 $(0.0865 \mathrm{MPa})$ で時間を変化させた場合であり， 遠心分離と同様にトゥフは 20 分程度で安定したが，ダイ コンの残さ重量比はその後もわずかに減少し続けた。 
以上のダイコンとトウフの結果から, 脱水操作条件は, 遠心分離の場合 $2328 \mathrm{xg}, 30$ 分間, 荷重压搾において は $0.0865 \mathrm{MPa}, 30$ 分間とした。

\section{3 凍結・解凍・脱水操作による試料食品の変化}

以上の凍結 · 解凍 ・脱水操作の条件にしたがって処理 した食品変化の典型的な例として，Fig．5にキャベッ の芯とコンニャクの, 生の状態, 凍結 - 解凍 · 遠心分離 後の状態，および遠心分離のみを行った刘照試料の写真 を示す。キャべッの芯は組織が硬く脱水しにくい試料な ので, 対照は生の状態とあまり変わらなかったが、凍 結・解凍後遠心分離したものは組織が軟らかくなりかな り脱水された。コンニャクの対照試料は角が丸くなり少 し脱水さ机た程度であったが, 凍結・解凍 · 遠心分離後 は脱水されて干からびたようになった。このように凍 結 · 解凍処理と脱水操作を組み合わせると, 比較的簡 単な脱水操作によって干からびたような状態にまで脱水 することができた。試料食品がさいころ状に切断されて いるのは, 食品の部位差を平均化するために $7 \sim 8 \mathrm{~mm}$ 角に切断して均一に混ぜて測定したためである。

\section{4 各食品の凍結・解凍・脱水操作による減量効果}

次に食品グループ別に凍結・解凍 ·脱水操作による減 量結果を Table $2 \sim 7$ にまとめ, 処理前の水分含量 (wt \%), 凍結・解凍しないで遠心分離した場合の無処理 と比較した残さ重量比 (wt \%) (対照), 凍結・解凍·遠 心分離後の残さ重量比 (wt \%), 凍結 · 解凍 · 荷重压搾 後の残さ重量比 ( wt \%), 凍結·解凍 · 遠心分離後の水 分含量（wt\%），を示した。

Table 2 には野菜・果物の調理くず 11 種の結果示 した。調理くずの水分含量は平均 $87.9 \%$ とかなり多い
が，組織が硬いために凍結・解凍処理しない場合は脱水 率が低く，とくに皮類は残さ重量比 $95 \%$ 以上のものが 多かった。しかし凍結・解凍・脱水処理により，ダイコ ンの皮（残さ重量比 $19.2 \%$, 遠心分離），パイナップル の芯（同 $15.1 \%$, 荷重圧控）などに扎て極めて高い脱 水効果が得られた。Fig. 5 に示したキャべッの芯の残 さ重量比は 38.8\%（遠心分離）であった。粘質成分があ るサトイモの皮（残さ重量比約 $72 \%$ ），や水分含量の少

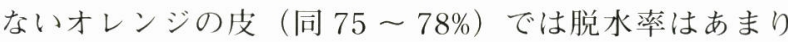
高くなかったが，対照と比較するとかなりよく脱水した。 これらの試料の凍結・解凍 ·脱水後の残さ重量比を平均 すると，遠心分離，荷重圧搾ともに $40 \%$ 程度にまで減 少しており，対照の $88.5 \%$ と比較するとかなり高い脱水 率であった。また水分含量は処理前の平均 $87.9 \%$ から $76.2 \%$ まで減少した。

Table 3 には水分含量 $90 \%$ 以上の野菜・果物（可食 部）11種の結果を示した。脱水処理のみ行った対照の 平均残さ重量比は $86.5 \%$ であったが、今回の測定は部位 差を考虑して $7 〜 8 \mathrm{~mm}$ 角に切断したために，切断に よる組織破壊の影響も含まれたと思われる。凍結・解凍 後の脱水では組織の軟らかいコマッナ（残さ重量比 $21.8 \%$ ，遠心分離；同 $19.9 \%$ ，荷重圧搾），ナス（同 $31.3 \%$ ，遠心分離；同 $33.2 \%$ ，荷重圧搾），に打いてはか なり減量した。ダイコン（残さ重量比 $58.4 \%$, 遠心分 離；同 $26.3 \%$, 荷重圧搾），キュウリ（同 $63.0 \%$ ，遠心 分離；同 $51.0 \%$ ，荷重圧搾），ニンジン（同 $68.6 \%$, 遠 心分離；同 $51.9 \%$ ，荷重圧搾），のように組織が硬いも のは荷重压搾でつぶした方が脱水率が高いようであっ た。これらの試料の凍結・解凍・脱水後の残さ重量比を 平均すると, 遠心分離後 $48.0 \%$, 荷重圧搾後 $39.0 \%$ と少し 差が見られたが，対照の残さ重量比 $86.5 \%$ と比較する

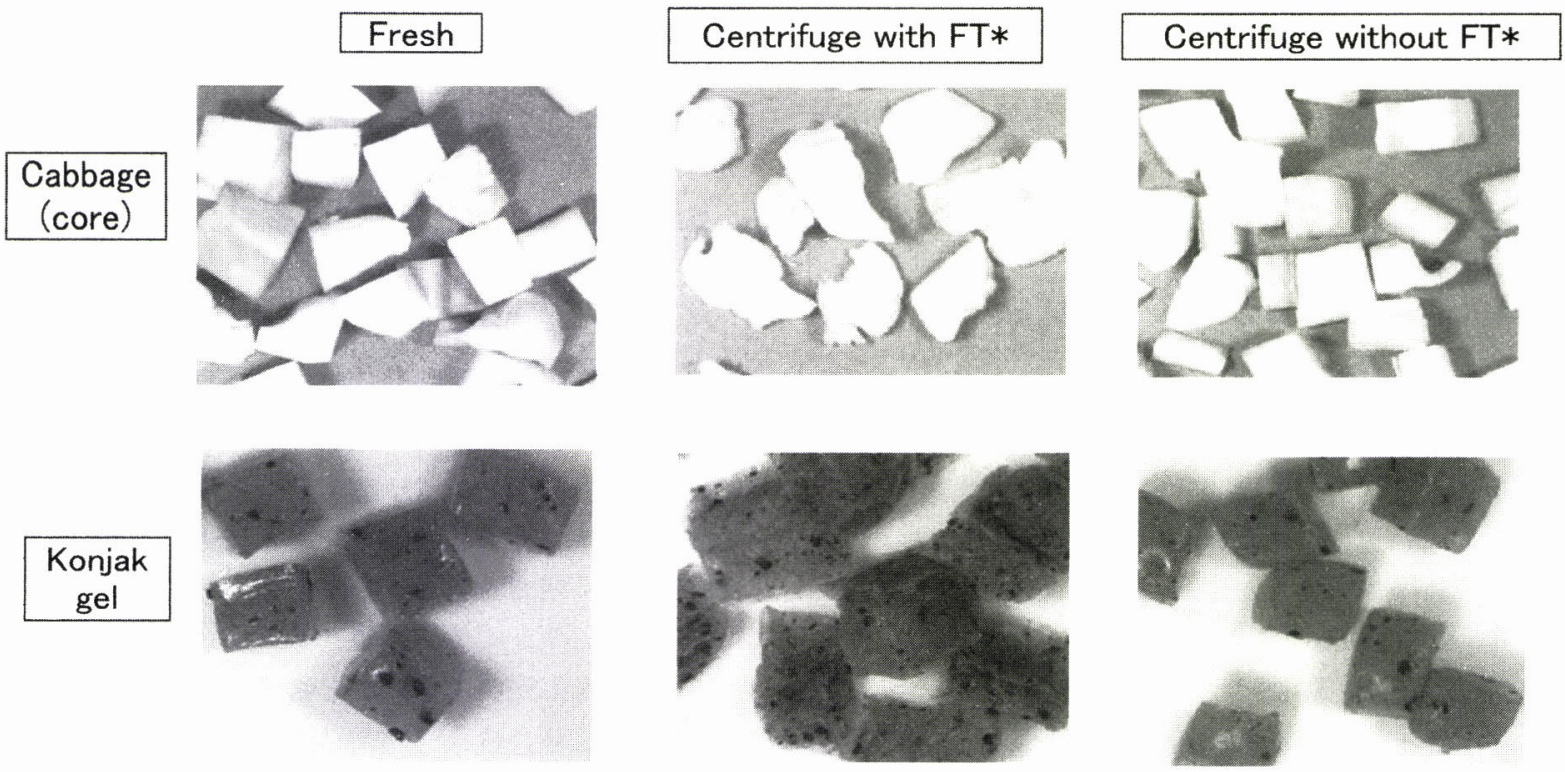

Fig. 5 Effect of centrifugation with or without freezing - thawing in cabbage core and konjak gel. $\mathrm{FT}^{*}$ ) freezing - thawing 
Table 2 Freezing-thawing dehydration of food waste.

\begin{tabular}{|c|c|c|c|c|c|}
\hline \multirow{3}{*}{ Sample } & \multirow{3}{*}{$\begin{array}{l}\text { Initial water } \\
\text { content }(w t \%)\end{array}$} & \multicolumn{3}{|c|}{ Residual weight fraction (wt\%) } & \multirow{3}{*}{$\begin{array}{c}\text { Final water } \\
\text { content } \\
\text { (wt\%) }\end{array}$} \\
\hline & & Centrifuge & Centrifuge & Compression & \\
\hline & & without $\mathrm{FT}^{*}$ & with $\mathrm{FT}^{*}$ & with $\mathrm{FT}^{*}$ & \\
\hline Watermelon (skin) & 94.5 & 97.6 & 23.3 & 26.0 & 76.3 \\
\hline Cabbage (core) & 94.3 & 92.9 & 38.8 & 30.8 & 85.3 \\
\hline Japanese radish (skin) & 94.1 & 98.4 & 19.2 & 30.8 & 69.5 \\
\hline Broccoli (stem) & 94.1 & 89.4 & 47.4 & 37.9 & 87.5 \\
\hline Banana (skin) & 91.2 & 85.8 & 45.9 & 38.6 & 80.9 \\
\hline Taro (skin) & 88.1 & 100.0 & 71.9 & 71.1 & 83.5 \\
\hline Pineapple (core) & 86.0 & 65.6 & 29.2 & 15.1 & 81.7 \\
\hline Apple (skin) & 84.5 & 84.5 & 31.6 & 28.7 & 74.6 \\
\hline Pineapple (rind) & 83.9 & 69.7 & 43.2 & 38.6 & 76.4 \\
\hline Potato (skin) & 79.9 & 96.3 & 43.0 & 48.3 & 53.3 \\
\hline Orange (peel) & 76.7 & 93.3 & 75.4 & 78.3 & 69.1 \\
\hline Average & 87.9 & 88.5 & 42.6 & 40.4 & 76.2 \\
\hline \pm & 6.3 & 11.5 & 17.9 & 19.0 & 9.7 \\
\hline
\end{tabular}

*) freezing-thawing

**) water content after centrifuge with FT

Table 3 Freezing - thawing dehydration of vegetables \& fruits (water content $>90 \%$ ).

\begin{tabular}{|c|c|c|c|c|c|}
\hline \multirow[b]{2}{*}{ Sample } & \multirow[b]{2}{*}{$\begin{array}{l}\text { Initial water } \\
\text { content ( } w t \%)\end{array}$} & \multicolumn{3}{|c|}{ Residual weight fraction (wt\%) } & \multirow{2}{*}{$\begin{array}{l}\text { Final water } \\
\text { content }^{* *} \\
(w t \%)\end{array}$} \\
\hline & & $\begin{array}{l}\text { Centrifuge } \\
\text { without } \mathrm{FT}^{*}\end{array}$ & $\begin{array}{l}\text { Centrifuge } \\
\text { with } \mathrm{FT}^{*}\end{array}$ & $\begin{array}{l}\text { Compression } \\
\text { with } \mathrm{FT}^{*}\end{array}$ & \\
\hline $\begin{array}{l}\text { Chinese cabbage } \\
\text { (Komatsuna) }\end{array}$ & 95.8 & 84.3 & 21.8 & 19.9 & 80.6 \\
\hline Japanese radish & 95.4 & 88.3 & 58.4 & 26.3 & 92.1 \\
\hline Cucumber & 95.3 & 89.9 & 63.0 & 51.0 & 92.5 \\
\hline Cabbage & 94.5 & 88.5 & 43.7 & 30.7 & 87.3 \\
\hline Eggplant & 94.0 & 94.6 & 31.3 & 33.2 & 81.0 \\
\hline Tomato & 93.8 & 87.4 & 45.9 & 38.3 & 86.5 \\
\hline Sweet pepper & 93.7 & 92.8 & 47.9 & 42.3 & 86.9 \\
\hline Asparagus & 93.2 & 76.3 & 46.8 & 41.0 & 85.6 \\
\hline Shiitake mushroom & 92.0 & 68.6 & 50.6 & 44.0 & 84.3 \\
\hline Carrot & 90.6 & 94.3 & 68.6 & 51.9 & 86.3 \\
\hline Broccoli & 90.2 & 86.6 & 50.6 & 50.8 & 80.5 \\
\hline Average & 93.5 & 86.5 & 48.0 & 39.0 & 85.8 \\
\hline \pm & 1.9 & 7.8 & 13.3 & 10.6 & 4.1 \\
\hline
\end{tabular}

*) freezing-thawing

**) water content after centrifuge with FT

と, いずれもかなり高い脱水率である。 また，水分含量 は处理前の平均 $93.5 \%$ から $85.8 \%$ まで減少した。

Table 4 には水分含量 $90 \%$ 以下の野菜 ·果物（可食 部) 4 種の結果を示した. 野菜は一般に水分含量が高い ので，水分含量 $90 \%$ 以下ではゴボウやサトイモのような 根菜類や糖分が多い果物などが対象となる. Table 4 を 3 と比較すると, 処理前の水分含量が平均 $80.8 \%$ と低い ために, 脱水処理のみの場合, 対照の残さ重量比は平均 95.1\%とほとんど脱水されなかった。しかしながら, 凍
結 - 解凍 ·脱水後の残さ重量比は, 遠心分離後平均 $58.4 \%$, 荷重圧搾後 $53.2 \%$ となり，この場合にもかなり 高い脱水効果を得ることができた. ジャガイモの脱水率 が比較的高く残さ重量比 $47.4 \%$ であったが, ゴボウは纎 維質であり，サトイモには糖タンパク質が含まれ粘度が 高いために脱水が妨げられたと考えられる. Table 4 に おける平均水分含量は処理前の平均 $80.8 \%$ から $66.1 \%$ ま で減少した。

Table 5 には肉と魚の例として鶏肉とマグロの結果を 
Table 4 Freezing-thawing dehydration of vegetables \& fruits (water content $<90 \%$ ).

\begin{tabular}{|c|c|c|c|c|c|}
\hline \multirow[b]{2}{*}{ Sample } & \multirow[b]{2}{*}{$\begin{array}{l}\text { Initial water } \\
\text { content ( } w t \%)\end{array}$} & \multicolumn{3}{|c|}{ Residual weight fraction (wt\%) } & \multirow[b]{2}{*}{$\begin{array}{c}\text { Final water } \\
\text { content }^{* *}(w t \%)\end{array}$} \\
\hline & & $\begin{array}{l}\text { Centrifuge } \\
\text { without FT* }\end{array}$ & $\begin{array}{l}\text { Centrifuge } \\
\text { with } \mathrm{FT}^{*}\end{array}$ & $\begin{array}{c}\text { Compression } \\
\text { with } \mathrm{FT}^{*}\end{array}$ & \\
\hline Burdock & 83.6 & 95.1 & 62.1 & 59.2 & 73.6 \\
\hline Taro & 81.2 & 97.3 & 65.6 & 55.8 & 71.3 \\
\hline Banana & 80.5 & 92.3 & $* * * *$ & 50.4 & $74.0^{* * *}$ \\
\hline Potato & 77.9 & 95.7 & 47.4 & 47.4 & 53.3 \\
\hline Average & 80.8 & 95.1 & 58.4 & 53.2 & 66.1 \\
\hline \pm & 2.3 & 2.1 & 9.7 & 5.3 & 11.1 \\
\hline
\end{tabular}

*) freezing-thawing

**) water content after centrifuge with FT

***) water content after compression with $\mathrm{FT}$

$* * * *$ ) accurate measurement is impossible

Table 5 Freezing-thawing dehydration of meat and fish.

\begin{tabular}{lccccc}
\hline \multirow{2}{*}{ Sample } & \multirow{2}{*}{$\begin{array}{c}\text { Initial water } \\
\text { content }(w t \%)\end{array}$} & $\begin{array}{c}\text { Residual weight fraction }(w t \%) \\
\text { Centrifuge } \\
\text { without } \mathrm{FT}^{*}\end{array}$ & $\begin{array}{c}\text { Centrifuge } \\
\text { with } \mathrm{FT}^{*}\end{array}$ & $\begin{array}{c}\text { Compressio } \\
\text { n with } \mathrm{FT}^{*}\end{array}$ & $\begin{array}{c}\text { Final water } \\
\text { content }\end{array}$ \\
\cline { 3 - 6 } Chicken & 73.7 & 96.7 & 100 & 100 & 73.9 \\
Tuna & 70.2 & 94.2 & 95.7 & 96.5 & 68.9 \\
\hline Average & 72.0 & 95.5 & 97.9 & 98.3 & 71.4 \\
\hline
\end{tabular}

*) freezing-thawing

**) water content after centrifuge with FT

Table 6 Freezing - thawing dehydration of gel materials.

\begin{tabular}{|c|c|c|c|c|c|}
\hline \multirow[b]{2}{*}{ Sample } & \multirow[b]{2}{*}{$\begin{array}{l}\text { Initial water } \\
\text { content }(w t \%)\end{array}$} & \multicolumn{3}{|c|}{ Residual weight fraction (wt\%) } & \multirow[b]{2}{*}{$\begin{array}{c}\text { Final water } \\
\text { content }^{* *}(w t \%)\end{array}$} \\
\hline & & $\begin{array}{c}\text { Centrifuge } \\
\text { without } \mathrm{FT}^{*}\end{array}$ & $\begin{array}{l}\text { Centrifuge } \\
\text { with } \mathrm{FT}^{*}\end{array}$ & $\begin{array}{c}\text { Compression } \\
\text { with } \mathrm{FT}^{*}\end{array}$ & \\
\hline Konjak gel & 97.2 & 71.8 & 29.1 & 29.1 & 90.3 \\
\hline Boiled egg white & 88.3 & 86.3 & 57.4 & 60.6 & 79.6 \\
\hline Soybean curd & 86.5 & 71.8 & 35.8 & 33.3 & 62.3 \\
\hline Kamaboko & 77.2 & 95.7 & 86.2 & 87.6 & 73.6 \\
\hline Average & 87.3 & 81.4 & 52.1 & 52.7 & 76.4 \\
\hline \pm & 8.2 & 11.7 & 25.7 & 27.2 & 11.7 \\
\hline
\end{tabular}

*) freezing-thawing

**) water content after centrifuge with FT

示した。肉や魚は凍結・解凍による脱水効果はほとんど 見られず, 脱水後残さ重量比はいずれも $95 \%$ 以上であ り, 水分含量も変化しなかった。この結果から見ても，肉 や魚は植物性食品と比較すると凍結耐性が強いと言える.

Table 6 にはゲル状食品として多糖類系ゲルのコンニャ クとタンパク質系ゲルの卵白, トウフ, カマボコの結果 を示した。コンニャクは水分含量が非常に高い食品 (97.2\%) であるが, 対照の残さ重量比は $71.8 \%$ まで下が った.しかしこれは測定のために $7 \sim 8 \mathrm{~mm}$ 角に切断 した影響が大きいと考えられる。凍結・解凍・脱水後の 残さ重量比は29.1\%（遠心分離，荷重压搾）（Fig. 5) とさらに大きく下がった。コンニャクを凍結したシミコ
ンニャクという加工食品もあるが，凍結・解凍したコン ニャクはスポンジ状に小孔が開き独特のテクスチャーを 示した。卵白ゲルの凍結・解凍・脱水後の残さ重量比 は 57.4\%（遠心分離）であったが，コンニャクほどの脱 水効果は見られなかった。 トゥフの凍結・解凍・脱水後 の残さ重量比は $33.3 \%$ (荷重圧搾) にまで下がったが, トウフは凍結変性により組織がスポンジ状に変化したた めと考えられる。かまぼこは水分含量が $77.2 \%$ と比較的 低い食品なので, 凍結・解凍・脱水後の残さ重量比は $86.2 \%$ (遠心分離) とあまり下がらなかったが, 脱水後の 水分は $73.6 \%$ まで下がった. ゲル状食品の平均水分含量 は処理前の $87.3 \%$ から $76.4 \%$ にまで減少した。 
Table 7 Freezing-thawing dehydration of cooked food.

\begin{tabular}{|c|c|c|c|c|c|}
\hline \multirow[b]{2}{*}{ Sample } & \multirow[b]{2}{*}{$\begin{array}{l}\text { Initial water } \\
\left.\text { content ( } w t^{2}\right)\end{array}$} & \multicolumn{3}{|c|}{ Residual weight fraction (wt\%) } & \multirow[b]{2}{*}{$\begin{array}{c}\text { Final water } \\
\text { content }^{* *}(w t \%)\end{array}$} \\
\hline & & $\begin{array}{l}\text { Centrifuge } \\
\text { without FT* }\end{array}$ & $\begin{array}{c}\text { Centrifuge } \\
\text { with } \mathrm{FT}^{*}\end{array}$ & $\begin{array}{l}\text { Compression } \\
\text { with } \mathrm{FT}^{*}\end{array}$ & \\
\hline Boiled japanese radish & 96.2 & 73.3 & 58.4 & 35.1 & 93.5 \\
\hline Boiled potato & 76.5 & 95.5 & 61.5 & 65.7 & 61.8 \\
\hline Boiled chicken & 68.2 & 82.8 & 83.0 & 86.3 & 61.7 \\
\hline Japanese noodles & 67.0 & 98.1 & 82.5 & 85.9 & 60 \\
\hline Cooked rice & 63.4 & 92.7 & 97.6 & 94 & 62.5 \\
\hline Average & 74.3 & 88.5 & 76.6 & 73.4 & 67.9 \\
\hline \pm & 13.2 & 10.3 & 16.4 & 23.8 & 14.3 \\
\hline
\end{tabular}

*) freezing-thawing

**) water content after centrifuge with FT

Table 7 には調理食品に対する結果を示した。食品は 加熱によって細胞組織の破壊，でんぷん糊化，タンパク 質変性などの諸変化が起こるので, 凍結・解凍による影 響は生鮮食品とは異なってくる。食品廃棄物の食べ残し は調理済みが多いので，参考にするために一般野菜のダ イコン，でんぷんが多いジャガイモ，動物性の鵎肉，主 食の飯，うどんについて調べた。加熱したダイコンを新 鮮材料と比較すると，対照の残さ重量比は $15 \%$ 程度下 がって $73.3 \%$ であったが，凍結・解凍・脱水後は新鮮の 場合と同様に大きな脱水効果が得られ，残さ重量比は 35.1\%（荷重圧搾）であった。加熱によりでんぷんが糊 化したジャガイモの対照はほとんど脱水されなかったが (残さ重量比 95.5\%)，糊化でんぷん食品であるうどんと 飯も同様であった。しかし，これらの食品も凍結・解凍 後は水分含量に応じてジャガイモ，うどん，飯の順に脱 水が見られた。これらの食品の最終的な水分含量はいず
れも $60 \%$ 強であり，この付近が糊化でんぷんとの結合 が強い水分の脱水限界ではないかと推測された。鶏肉は 加熱により収縮して水分含量は生より $5 \%$ ほど減少して $68.2 \%$ になった。脱水効果は加熱肉の方が生肉よりも高 かったが, 凍結・解凍処理による効果は見られなかっ た. 以上の調理食品の結果を平均すると, 調理後に凍 結・解凍・脱水を行った試料は加熱と脱水を組み合わせ た対照よりも残さ重量比は $10 １ 5 \%$ 低く，水分含量は $74.3 \%$ から $67.9 \%$ まで減少したので, 調理食品において も凍結・解凍操作により, かなりの脱水効果が得られる ことがわかった。

以上の結果から各食品グループにおける, 遠心脱水の みを行った対照の残さ重量比平均值と, 凍結・解凍 · 遠心脱水処理後の残さ重量比平均值を Fig. 6 に示す. 対照の残さ重量比はもっとも少ないゲル状食品でも平均 $81.4 \%$ ，それ以外の食品グループでは $90 \%$ 前後から $95 \%$

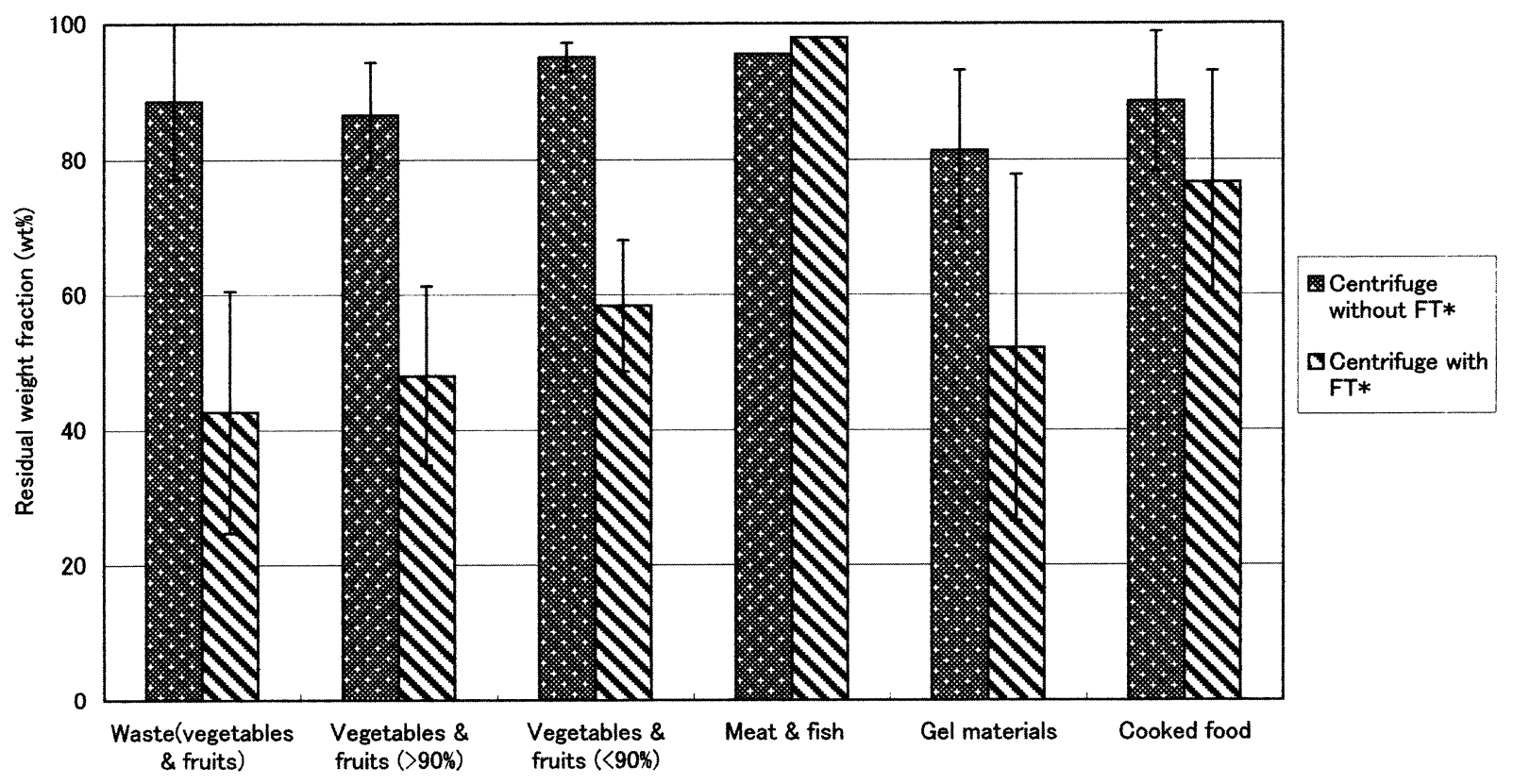

Fig. 6 Freezing - thawing dehydration of various foods.

$\mathrm{FT}^{\star}$ ) freezing - thawing 
以上の值であり脱水効果はあまり見られなかった。これ に対して，凍結・解凍処理をした試料では，組織の硬い 野菜・果物の調理くずにもっとも脱水効果が見られ，残 さ重量比は対照の $1 / 2$ 以下にまで減少した。また野菜。 果物，ゲル状食品の脱水効果は高く，残さ重量比は 40 一 $60 \%$ 以下とほぼ半減した。調理食品に打いても脱水効果 が見られた。さらに、これら凍結・解凍処理により顕著 な脱水効果が見られた試料は，いずれも，処理後の状態 が半乾燥状態に近くなっており, 廃棄物としてのハンド リング性が大きく向上した。

\section{4. 考察}

以上により，凍結・解凍処理は野菜・果物類抢よびそ れらの調理くずの脱水効果促進に大きな意義があること がわかった。一般に植物細胞は, 細胞膜構造で仕切られ た緻密な細胞構造の集合体で形成されているが，このた め, 植物細胞は大きな電気抵抗を示し [12]，複素インピー ダンス測定により。この細胞構造に対応するCole-Cole の川弧[13]を観測することができるが，凍結処理により， この Cole-Cole の川弧は完全に消失し, 絊胞構造が完 全に破壊されることが報告されている[7]。このことは， 植物細胞の膜構造が凍結に対して極めて脆弱であること を意味して抢り，そのために，凍結・解凍処理が脱水効 果促進に大きく寄与したものであろう。こ机に対して， 肉・魚などの可食部である筋肉細胞は, 細胞構造が植物 とはまったく異なっており，インピーダンス測定に打いて はCole-Coleの川弧はまったく観測されず[7]。さらに， 膜の水透過係数が植物と動物細胞とでは大きく異なって
おり，そのために細胞凍結に伴う細胞外凍結によって生 ずる凍結誘起浸透圧脱水に対する応答が両者でまったく 異なって打り、このことが凍結耐性に打ける大きな違い の原因であるとされている[4]。このために, 肉・魚で 法凍結・解凍操作により練胞構造は破壊されることはな く，したがって脱水促進効果が観測されなかったもので あろう。一方，ゲル状食品や調理食品は，前者は細胞構 造を持たず，後者は加熱によりすでに細胞構造は破壊さ れているが，凍結に伴う微細水結晶生成に基ゔくミクロ な凍結濃縮効果により，タンパク質変性などが起こり このことが凍結・解凍処理による脱水効果促進に寄与し たものと思われる。この効果を反映してトウフやコンニャ クにおいては凍結・解凍後に大きなテクスチャー変化が 見られたものであろう。

今回測定したすべての試料の水分含量を平均すると， 処理前が $86.04 \%$, 凍結・解凍・脱水後が $76.9 \%$ であり 平均して約 $10 \%$ の水分減少効果が得られた。この水分 含量は, コンポスト化に打いて最適とされる水分含量 (74 7 76\%) [14]とほぼ一致する值であり, 凍結・解 凍・脱水操作が食品廃棄物コンポスト化の前処理として も有効であることを示唆した。また, 脱水は従来通り厨 芥類を焼却する場合にもかなりの省工ネルギーになり， 同時に廃枀物の減量にもなる。そこで，食品廃棄物排出 源の約半分をしめる家庭の生ゴミ（厨芥類）全体に対し て, 凍結・解凍・脱水処理を行った場合にどの程度の減 量が見込めるかについて，今回の測定結果を用いて試算 した。Fig. 7A は京都市環境局による家庭系食品廃㶳物 調查（平成 9 年）[2]をもとに作製した円グラフである. 家庭系食品廃萊物は大きく調理くず、食べ残し，その他

\section{Statistics for kitchen refuse*}

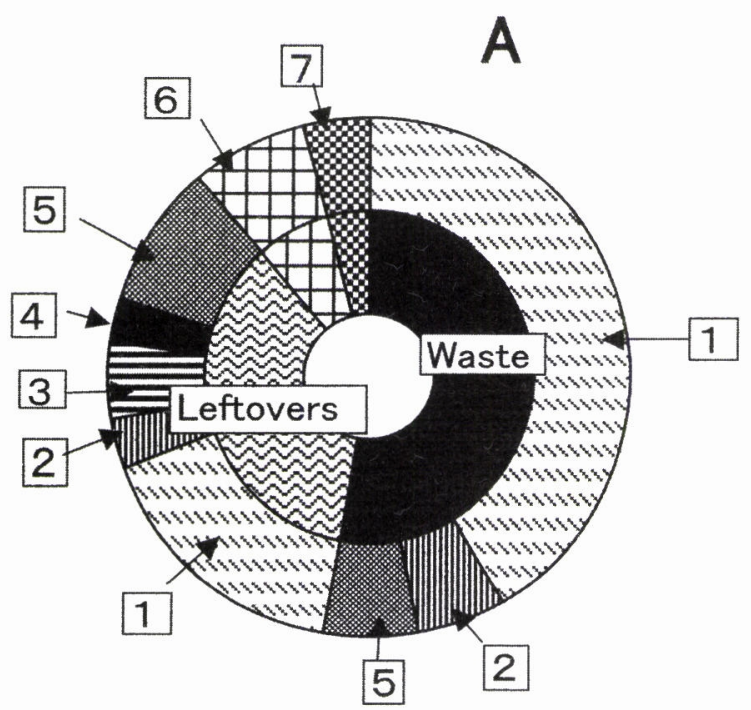

\section{Dehydration effect for kitchen refuse}
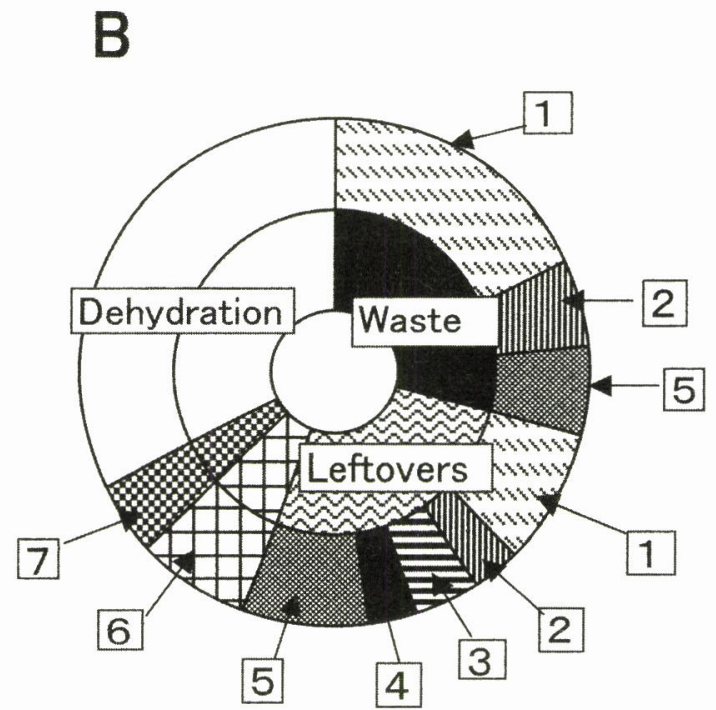

Fig. 7 Estimation of the dehydration effect for kitchen refuse by freezing-thawing-dehydration treatment. 1. Vegetables \& fruits, 2. Meat, egg \& fish, 3. Cooked rice \& noodles, 4. Bread \& sweets, 5. the Others, 6. Taste, 7. Drained water.

*) From "Research of the Kyoto - City Environmental Center (1997)" 
嗜好品など，に分類される。調理くずでは素材から購入 する野菜・果物のくずが多くを占め, 肉や魚は可食部を 購入することが多いので，くずとしては卵の款や魚のあ らなどである。食べ残しも野菜・果物がもっとも多く， 飯, 麺類, パンなどの主食品および肉・魚, その他があ げられる. Fig. 7B は Table $2 \sim 7$ の平均残さ重量比を 用いて凍結・解凍・脱水による厨芥類全体に対する減量 効果を試算した結果である。脱水による減量は全体の $32.5 \%$ ，流出水分 $4.2 \%$ を加えると $36.7 \%$ の減量が試算さ れた。このように大きな減量効果が得られた理由として は, 家庭系廃棄物では野菜・果物に由来する厨芥類の 割合がかなり大きく，野菜・果物の調理くずは全体の $41.5 \%$ ，野菜・果物の食べ残しが全体の $16.5 \%$ を占める ことが挙げられる。以上から凍結・解凍・脱水処理は家 庭系厨芥類のような植物系残さが多い食品廃棄物の脱水 および減量にはきわめて有効と考えられる. 本方法はガ ス等の発生もなく安全な方法であり，さきに述べたよう に省エネルギ一的である。また，脱水減少部分をそのま ま下水へ排水しても $\mathrm{N}$ 化合物は少なく他の成分も希薄 で, 排水全体に占める割合としては無視可能であり，排 水負荷にはほとんど影響しないと考えられる。したがっ て本方法は，その大きな減量効果とハンドリング性の向 上により，厨芥類の輸送および焼却処分において有効で あるばかりでなく，コンポスト化の前処理としても有効 性が期待される。

謝辞 本研究を実施するに当たり，実験にご協力頂きま した実践女子大学生活科学部調理学第 3 研究室の中町 敦子, 川上千絵美, 玉井咲子, 野原愛子, 藤田亜矢子, 影森裕子, 丹野陽子, 野澤雅代, 袴田美紗子, 平林佳子, 福原智恵の諸寋に深く感謝致します.

\section{引用文 献}

1) 平成 8 年厚生省資料等から推計.

2）平成 9 年度京都市環境局資料により環境庁作成.

3) E. Ishikawa, S. K. Bae, O. Miyawaki, K. Nakamura; Freezing injury of cultured rice cells analyzed by dielectric measurement. J. Ferment. Bioeng., 83, $222-226$ (1997).

4) E. Ishikawa, O. Miyawaki, K. Nakamura; Water permeability of plasma membranes of cultured rice, grape, and CH27 cells measured dielectrically. Biosci. Biotech. Biochem., 61, 1826-1830 (1997).

5) S. Ohnishi, T. Fujii, O. Miyawaki; Electrical and rheological analysis of freezing injury of agricultural products. Intern. J. Food Propert., 5, 317-332 (2002).

6) P. Dejmek, O.Miyawaki; Relationship between the electrical and rheological properties of potato tuber tissue after various forms of processing. Biosci. Biotech. Biochem.,
66, $1218-1223$ (2002).

7）宮脇長人，四宮陽子；食品廃棄物の凍結・解凍・脱水処理, 化学工学論文集, 28，618-620（2002）.

8) 井出哲夫, 川崎健二, 山城博隆, 松田 晃; 余剩活性污泥 の凍結融解処理一凍結温度の影響一, 下水道協会誌, 23 (265)，21-30 (1986).

9）川崎健二, 石川和久, 山城博隆, 松田晃, 井出哲夫; 余 剩活性污泥の凍結融解処理一凍結速度の影響一, 水質污濁 研究, 11, 520-526 (1988).

10）加藤舜郎; “食品冷凍の理論と応用”, 光琳書院, 1970, p. 324 .

11）闵藤貴美子; 冷凍魚の解凍について, 調理科学, 29, 67-72 (1996).

12) M. I. N. Zhang, D. G. Stout, J. H. M. Willison; Electrical Impedance Analysis in Plant Tissues: Symplasmic Resistance and Membrane Capacitance in the Hayden Model. J. Exper. Botany, 41, 371-380 (1990).

13) E. S. Cole; Electrical Phase Angle of Cell Membrane. J. Gen. Physiol., 15, 641-649 (1932).

14）藤田賢二；“コンポスト化技術一廃棄物有効利用のテクノ ロジー”, 技報堂出版, 1998, p.65.

\section{引 用 URL}

i) http://www.mew.co.jp/kurashi/kankyo/gomi.html （環境省；くらしのメモ，環境シリーズ，ごみ問題編）

ii) http://www.maff.go.jp/sogo_shokuryo/data/051 shokkanshitsu.../kenkyuukai_gaiyou.ht

(農林水産省; 食品循環資源の再生利用等の促進に 関する法律)

iii) http://www.maff.go.jp/soshiki/kambou/kikaku/ hyoka/13sh06.pdf

(農林水産省; 平成 13 年度農林水産省政策評価実 施方針)

\section{要旨}

省エネルギ一的な食品廃棄物の減量処理法として, 凍 結・解凍・脱水法について検討した。試料は野菜, 果 物, それらの調理くず, 肉や魚, ゲル状食品, 加熱食品 から約 40 種類を選択した。それらの試料を凍結・解凍 処理ののち，遠心分離または荷重圧搾で脱水した。凍 結・解凍・脱水法は肉や魚にはそれほど効果はなかった が, 野菜, 果物, それらの調理くず, ゲル状食品に対し ては大きな効果があり，40 から $60 \%$ の減量効果が得られ， また全試料の平均水分含量は, 本操作により $86.0 \%$ から $76.9 \%$ に減少した。以上の実験結果と統計データを用い て台所の生ゴミ全体について, 凍結・解凍・脱水効果を 試算したところ約 $37 \%$ の減量効果が予測された。本方 法は食品廃棄物の輸送，焼却，コンポスト化のいずれに 対しても有効であることが期待される。 